\section{Late-stage diagnosis of HIV infection in Brazilian children: evidence from two national cohort studies}

\author{
Diagnóstico tardio da infecção por HIV em crianças \\ brasileiras: evidências baseadas em dois estudos \\ nacionais de coorte
}

\author{
Diagnóstico tardío de la infección por $\mathrm{VIH}$ en niños \\ brasileños: evidencias basadas en dos estudios \\ nacionales de cohorte
}

\author{
Alberto Novaes Ramos Jr. 1 \\ Luiza Harunari Matida 2 \\ Carlos Henrique Alencar 1 \\ Norman Hearst 3 \\ Jorg Heukelbach 1
}

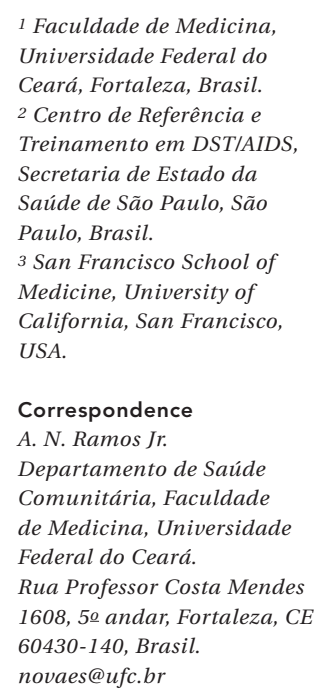

${ }^{1}$ Faculdade de Medicina, Universidade Federal do Ceará, Fortaleza, Brasil. 2 Centro de Referência e Treinamento em DST/AIDS, Secretaria de Estado da Saúde de São Paulo, São Paulo, Brasil.

${ }^{3}$ San Francisco School of Medicine, University of California, San Francisco, USA.

Correspondence A. N. Ramos Jr. Departamento de Saúde Comunitária, Faculdade de Medicina, Universidade Federal do Ceará. Rua Professor Costa Mendes 1608, 5o andar, Fortaleza, $C E$ 60430-140, Brasil.

novaes@ufc.br

\begin{abstract}
This study analyzed data from two consecutive retrospective cohort samples (1983 to 1998 and 1999 to 2002) of Brazilian children with AIDS $(N=1,758)$ through mother-to-child-transmission. Late-stage diagnosis (CDC category C) was investigated in relation to the following variables: year of birth, year of HIV diagnosis, and time periods related to changes in government treatment guidelines. Late-stage diagnosis occurred in 731 (41.6\%) of cases and was more prevalent in infants under 12 months of age. The rate of late-stage diagnosis decreased from $48 \%$ to $36 \%$ between the two periods studied. We also observed a reduction in the proportion of latestage diagnoses and the time lapse between HIV diagnosis and ART initiation. A significant association was found between timely diagnosis and having been born in recent years $(O R=0.62$; $p=0.009)$ and year of HIV diagnosis (OR $=0.72$; $p=0.002 / O R=0.62 ; p<0.001)$. Infants under the age of 12 months were more likely to be diagnosed at a late stage than older children $(O R=$ $1.70 ; p=0.004$ ). Despite advances, there is a need to improve the effectiveness of policies and programs focused on improving early diagnosis and management of HIVIAIDS.
\end{abstract}

HIV; Delayed Diagnosis; Child

\section{Resumo}

Analisaram-se dados de duas coortes retrospectivas consecutivas (1983-1998, 1999-2002) de crianças brasileiras com AIDS ( $n=1.758)$, expostas ao HIV por transmissão vertical. Ocorrência de diagnóstico tardio (categoria $C$ - $C D C$ ) foi verificada para: ano de nascimento, ano de diagnóstico da infecção e períodos relacionados a mudanças das diretrizes terapêuticas governamentais. Encontramos 731 (41,6\%) crianças com diagnóstico em estágio tardio, especialmente com $<1$ ano de idade. No segundo período o desempenho do diagnóstico melhorou (36 vs. $48 \%$ de atraso diagnóstico no primeiro período). Verificou-se melhoria da proporção de crianças com diagnóstico tardio e do tempo entre o diagnóstico da infecção e a introdução da terapia antirretroviral. Ano de nascimento $(\mathrm{OR}=0,62$ $p=0,009)$ e ano de diagnóstico da infecção (OR $=0,72 ; p=0,002 / O R=0,62 ; p<0,001)$ mais recentes estiveram significativamente associados a diagnóstico oportuno. Crianças com idade $<1$ ano tiveram maior risco para diagnóstico tardio do que as mais velhas (OR=1,70; $p=0,004)$. Apesar dos avanços, há necessidade de potencializar diagnóstico e manejo oportunos.

HIV; Diagnóstico Tardio; Criança 


\section{Introduction}

The implementation of national health system programs to promote early HIV diagnosis in pregnant women is a fundamental strategy to prevent mother-to-child transmission of the disease 1 . In addition, early and effective diagnosis increases the possibility of delaying progression to AIDS and mortality in children 2,3.

HIV replication plays an important role in disease pathogenesis 6,7 and early antiretroviral treatment (ART) in children has been shown to be associated with long-term control of HIV-1 replication and improved clinical and immunological outcomes 4,5,6.

A study of children under the age of 12 months in the United States showed that highly active antiretroviral therapy (HAART) reduced mortality by $76 \%$, and progression of the infection by $75 \% 5$, showing that this treatment changes the natural course of HIV infection in children 4 . New clinical and epidemiological patterns have been observed in both developed 8 and developing countries 9

Brazil's national HIV/AIDS control policy is widely recognized as a model, particularly for developing countries 10 . The Brazilian government has been guaranteeing free access to HAART for all positively diagnosed individuals since 1996 11, resulting in a clear reduction in mother-to-child transmission of HIV, hospitalizations and general morbidity and mortality related to AIDS $11,12,13,14,15,16$. Two retrospective cohort studies of children diagnosed with AIDS in two distinct periods (1983 to 1998 and 1999 to 2002) showed a $52.8 \%$ and $88.3 \%$ increase in probability of survival after 60 months 17, However, a populationbased study of 84,694 patients aged 15 years or over showed that a high proportion of patients undertaking HAART began at an advanced stage of the infection 18 . This scenario reinforces the need to review strategies within the Brazilian Unified National Health System (SUS) aimed at ensuring early diagnosis.

There are no population-based studies investigating temporal patterns of the timing of HIV diagnosis among the child population of Brazil ( $<13$ years of age). This study examined patterns of late-stage diagnosis of HIV/AIDS in children based on data from the above mentioned national cohort studies.

\section{Methods}

\section{Study design and population}

This study is based on data from two multicenter retrospective cohort survival studies of Brazilian children with AIDS. Both studies are historical cohorts and methodology has been described previously in detail 19,20,21. The sample included individuals under the age of 13 based on the national AIDS case definition of children 11. The two child cohorts comprised probability samples of children infected with AIDS via mother-to-child transmission of the virus selected from the national database of reported AIDS cases (Information System for Notifiable Diseases - SINAN, acronym in Portuguese).

The sample included a total of 1,859 children; 914 (49.2\%) from the first study, and 945 (50.8\%) from the second. The first study included children diagnosed with AIDS between January 1st 1983 and December 31st 1998. The definition of the status of the children (dead or alive) was based on follow-up until death or the end of 2002. The second study was composed of children diagnosed between January 1st 1999 and December 31st 2002 and followed up until death or the end of 200717,20 .

\section{Definitions and data analysis}

Late stage diagnosis was defined as clinical category "C" at the moment of HIV diagnosis. We identified the first registered clinical evaluation of the patient and classified the disease according to clinical categories based on signs or symptoms associated with HIV infection. The classification used was based on the revised system for HIV infection in children of the Centers for Disease Control and Prevention (CDC) 22.

Category " $\mathrm{C}$ " includes all AIDS-defining conditions except lymphoid interstitial pneumonia 22 , and thus was considered an advanced stage of the disease. Category " $N$ " includes nonsymptomatic diseases with no signs or symptoms associated with HIV infection, or with only one of the mildly symptomatic conditions listed in category "A". Category "B" includes all children with signs or symptoms possibly caused by HIV infection, but not listed under category "A" or category "C".

Time trends of late stage diagnosis were analyzed by year of HIV diagnosis, year of birth and year of ART initiation.

Epidemiological and demographic variables were documented. Using bivariate analysis, we verified the association of late-stage diagnosis with the following exposure variables: gender, 
study cohort/year of HIV diagnosis (1983 to 1998 or 1999 to 2002), age at time of HIV diagnosis (< one, one to five, and six to 12 years). We stratified year of birth into three groups according to the history of pre-HAART and HAART in Brazil: before 1988 (ART not available); 1989 to 1995 (limited ART availability); 1996 to 2002 (ART available nation-wide, more consistent use of ART with Brazilian children (HAART available), and widespread implementation of first national ART guidelines and of strategies to prevent motherto-child transmission 11. For year of HIV diagnosis (before 1996, 1996 to 2007) and year of death (before 1996, 1996 to 2007) we defined two periods (pre-HAART and post-HAART). Odds ratios (OR) with their respective 95\% confidence intervals $(95 \% \mathrm{CI})$ were calculated. Significance of association between variables was verified using the chi-squared test. Data regarding CD4 lymphocyte counts is presented only for the last period (1999 to 2002), since detailed information on CD4 counts was only available from 1999. The sample was grouped into the following age categories (under 12 months, one to five years, and six to 12 years). Data was analyzed using the Stata 11.0 software package (Stata Corp., College Station, USA).

\section{Ethical considerations}

Both cohort studies were approved according to National Health Council guidelines by the Ethical Review Boards of the Center for Reference and Training in STD/AIDS of the State of São Paulo.

\section{Results}

Information on the clinical stage of the disease at the moment of HIV diagnosis was available in $1,758(94.6 \%)$ of the 1,859 cases, of which 1,027 (58.4\%) were not late-stage diagnoses and 731 (41.6\%) were late-stage diagnoses. A total of 818 (46.5\%) children had already been diagnosed with AIDS at the moment of HIV diagnosis. Prevalence of late-stage diagnosis was significantly lower in children from the second cohort (1999 to 2002) and also in the second and third age categories and in individuals diagnosed with HIV in the second study period (1996 to 2002). The majority of children were between one and five years of age at the moment of HIV diagnosis. Children under 12 months of age at the moment of HIV diagnosis were more likely to be diagnosed at a late stage; this association was significant. No gender differences were found (Table 1).

The children were classified into the following clinical categories of HIV infection: "N" = 95
(5.4\%) ; “A” = 342 (19.5\%) , "B" = 590 (33.6\%) , and "C" $=731(41.6 \%)$.

We observed an initial reduction in the frequency of category "C" from $66.7 \%$ in 1982 to $37.3 \%$ in 1989. Thereafter, the proportion of cases in this category stabilized at around $40 \%$ in 2002. Category "C" was the most common category across all age groups in each time period, with a relative reduction from $50.6 \%$ in 1989 to $30.8 \%$ 2002.

With regard to ART initiation, a consistent reduction in the prevalence of late-stage HIV diagnosis occurred after 1996, indicating early introduction of medication. The prevalence of timely ART initiation increased over the study period; in $199753.5 \%$ of children receiving ART were latestage diagnosis cases, compared to $29 \%$ in 2002 (Figure 1).

The time lapse between birth and HIV diagnosis varied from less than one to 12 years. This time lapse was shorter in the 1996 to 2002 cohort, where the majority of cases $(457,53.1 \%)$ were diagnosed within the first year. It took the following length of time to reach a $75 \%$ diagnosis rate in each time series: prior to 1988 - 36 seven years; 1989 to 1995 - five years; 1996 to 2002 - two years (Figure 2).

An analysis of the data of the first absolute CD4+ lymphocyte count for all children (945) in the 1999 to 2002 cohort revealed that children alive in the six to 12-year age group had mean and median values within the range defined by CDC as moderate immunological changes, whereas children in the under -12 months and one to five-year age groups had a low number of CD4+ T cells, and therefore immunological changes were classified as severe in the latter groups (Table 2).

\section{Discussion}

The data shows that, despite the success of Brazil's HIV/AIDS control policy 10,11, a large proportion $(42 \%)$ of children progressed to AIDS. The high proportion (40\%) of category "C" diagnoses in children born in recent years emphasizes the need to improve the effectiveness of HIV diagnosis programs and strategies directed at pregnant women and children. Furthermore, we observed a significant time lapse between birth and HIV diagnosis in all periods. However, results also indicate a comparative reduction in the proportion of delayed diagnoses and in the time lapse between HIV diagnosis and ART initiation.

Changes in epidemiological surveillance strategies for reporting AIDS cases in children over the last 25 years have led to improvements in the definition of criteria for HIV diagnosis and 


\begin{tabular}{|c|c|c|c|c|}
\hline & $\begin{array}{l}\text { Total } \\
\text { n (\%) }\end{array}$ & $\begin{array}{l}\text { Late-stage diagnosis } \\
\qquad \mathrm{n}(\%)\end{array}$ & OR $(95 \% \mathrm{Cl})$ & $\mathrm{p}$-value \\
\hline Total & $1,758(100.0)$ & $731(41.6)$ & - & - \\
\hline \multicolumn{5}{|l|}{ Gender } \\
\hline Male & $872(49.6)$ & 365 (41.9) & Reference & \\
\hline Female & $886(50.4)$ & $366(41.3)$ & $0.98(0.81-1.19)$ & 0.847 \\
\hline \multicolumn{5}{|c|}{ Study cohort (year of AIDS diagnosis) } \\
\hline 1983-1998 & $830(47.2)$ & $396(47.7)$ & Reference & - \\
\hline $1999-2002$ & $928(52.8)$ & $335(36.1)$ & $0.62(0.51-0.75)$ & $<0.001$ \\
\hline \multicolumn{5}{|l|}{ Year of birth } \\
\hline Before 1988 & $147(8.3)$ & 77 (52.4) & Reference & - \\
\hline 1989-1995 & $750(42.7)$ & $305(40.7)$ & $0.62(0.44-0.89)$ & 0.011 \\
\hline $1996-2002$ & $861(49.0)$ & $349(40.5)$ & $0.62(0.44-0.88)$ & 0.009 \\
\hline \multicolumn{5}{|c|}{ Age (years) at HIV diagnosis } \\
\hline$<1$ & $627(35.7)$ & $338(53.9)$ & $1.70(1.20-2.41)$ & 0.004 \\
\hline $1-5$ & $969(55.1)$ & $327(33.7)$ & $0.74(0.53-1.04)$ & 0.091 \\
\hline $6-12$ & $162(9.2)$ & $66(40.7)$ & Reference & - \\
\hline \multicolumn{5}{|c|}{ Year of HIV diagnosis } \\
\hline Before 1996 & $526(39.9)$ & $248(47.1)$ & Reference & - \\
\hline $1996-2002$ & $1,232(70.1)$ & $483(39.2)$ & $0.72(0.59-0.89)$ & 0.002 \\
\hline
\end{tabular}

OR: odds ratio; $95 \% \mathrm{Cl}$ : $95 \%$ confidence interval.

treatment and facilitated the comparison of data between different countries. These changes have been adapted to the Brazilian reality to ensure criteria sensitivity without compromising specificity 11 and can be directly related to the reduction in the birth-diagnosis time lapse observed in the second cohort (1999 to 2002). In fact, HIV diagnosis in children under two years of age in 1996 was based on the use of serological methods when the child reached the age of 18 to 24 months. However, with the introduction of molecular diagnostic techniques in August 1997, this diagnosis is carried out between two to four months of age 11 . In spite of the results presented by this study, early molecular diagnosis has enabled better management which, together with the increased availability of ART 14,15, has had a positive impact.

Late-stage HIV diagnosis leads to a delay in the onset of health care and hinders the achievement of better results $5,6,22$. This situation is related to a high incidence of infection, the risk of progression to AIDS and death (especially in children under the age of 12 months), health system costs, and reduced effectiveness of ART 9,11. Considering that since 1994 more than $90 \%$ of AIDS cases in Brazilian children are due to mother-to-child transmission, improving prevention actions not only avoids new infections but also enables the early diagnosis of infected children 13,15.

The rate of mother-to-child transmission was estimated at $16 \%$ (95\%CI: 13.0-20.9) during the early years of the AIDS epidemic (1988 to 1993) 23. Actions to reduce mother-to-child transmission of HIV became more consistent in Brazil after 1999 11,12. Another national study showed estimated transmission rates of $8.6 \%$ (95\%CI: 7.2-10.2) in 2000 and $7.1 \%$ (95\%CI: $5.8-8.6$ ) in 2001 24. More recently, a study conducted in São Paulo State showed that the rate of mother-tochild transmission of HIV was $2.7 \%$ (95\%CI: 1.863.94) 21 . However, the quality of health services directed at the control and management of HIV/ AIDS varies greatly in Brazil. This situation reflects the size of the country, large number of inhabitants (190 million) and social, economic and cultural inequality 25 , which explains the lack of reach of actions to control the rate of mother-tochild transmission and the inadequate management of exposed children 26 .

The analysis revealed that children under the age of 12 months are 1.7 times more likely to be subject to late-stage diagnosis and had higher rates of disease progression and mortality com- 


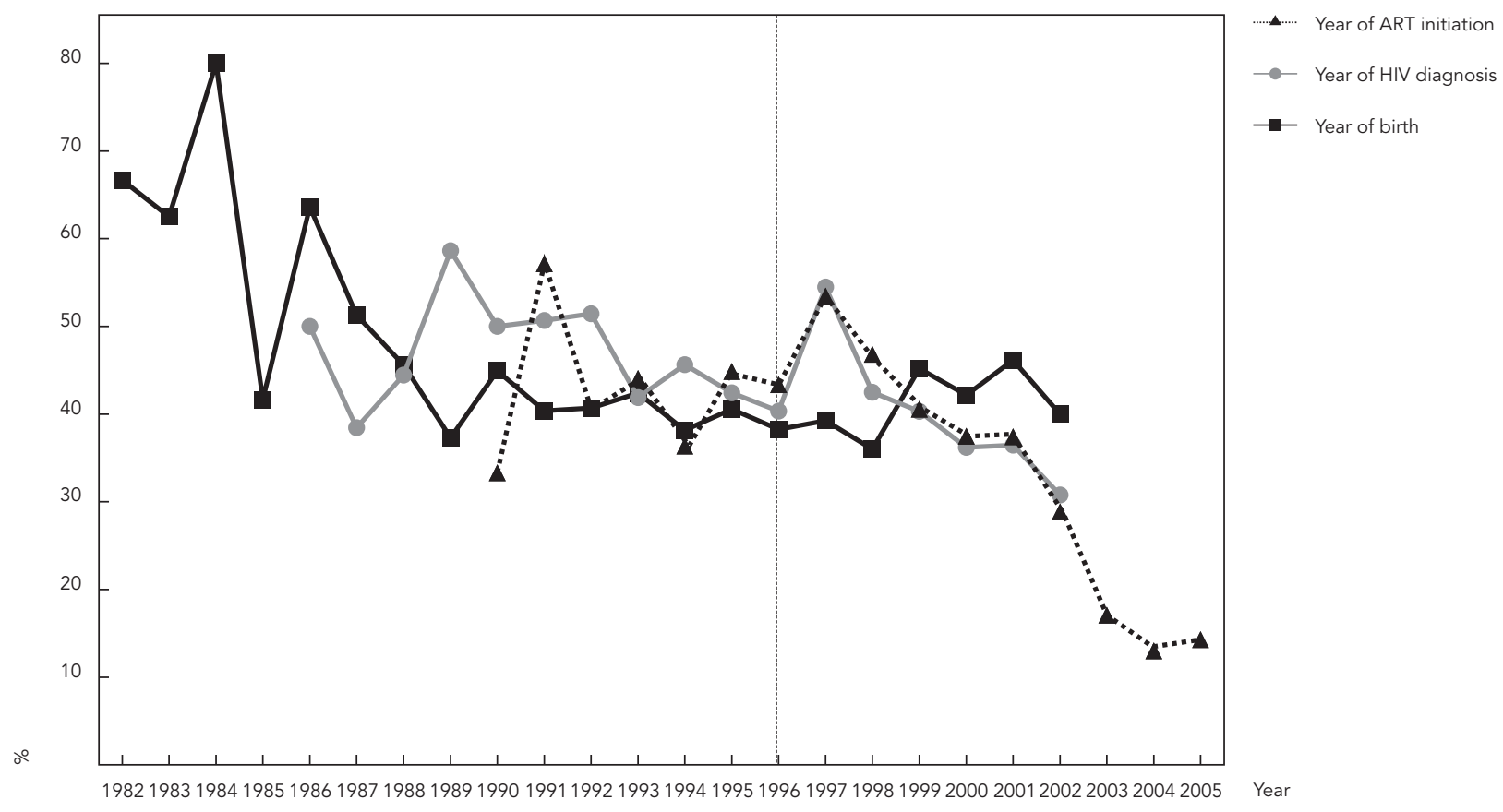

ART: antiretroviral treatment.

pared with older children 5,27,28,29, even in children with high CD4 cell counts ${ }^{30}$. Considering this high risk, all children in this age group should receive ART, regardless of clinical conditions, CD4 counts, or viral load 31 . This recommendation is also explicit in the Brazilian guidelines for treatment of children infected with HIV since 200932.

The CD4+ T cell count is an important marker for the analysis of the immune status of children and deciding when to initiate ART in children infected with HIV-1 31 . In this study we observed serious immunological changes at the time of the clinical classification of the HIV infection in all age groups, increasing the risk of progression to death without ART.

Children born or diagnosed with HIV/AIDS before HAART was made available were more likely to be diagnosed early, reflecting the efforts of the Brazilian government to guarantee universal access after 1996. These findings may also explain the large increase in survival between the two national studies 20 , showing the importance of ART for long term survival. Furthermore, a significant improvement in the clinical status of children was observed in the second study, therefore leading to a probable improvement in the quality of life of these children 20 . However, there is a continued need to improve the effectiveness of policies and programs focused on improving early diagnosis and management of HIV-infection.

Early diagnosis and ART initiation potentially reduces mortality, improves quality of life of infected children, and ensures proper growth and development $32,33,34,35$. Furthermore, it preserves, restores or improves the functioning of the immune system, thus reducing the likelihood of opportunistic infections, and provides maximum suppression of HIV replication by reducing the risk of drug resistance and toxicity 2,5,6,36. Moreover, prolonged ART strengthens the immune system of HIV-infected children 37 .

A study of 1,402 Italian children infected through mother-to-child transmission showed a reduction in the progression to AIDS between pre-HAART (1985 to 1995) and HAART (1996 to 2000 and 2001 to 2005) periods 38. In Brazil, a national study showed that HAART was associated with a reduction in the incidence of opportunistic infections 15. Despite a significant reduction in the incidence of opportunistic illnesses in Brazilian children with AIDS in the post-HAART 
Figure 2

Time lapse between birth and HIV diagnosis in children with AIDS stratified by year of birth (before 1988, 1989 to1995, and 1996 to2002).

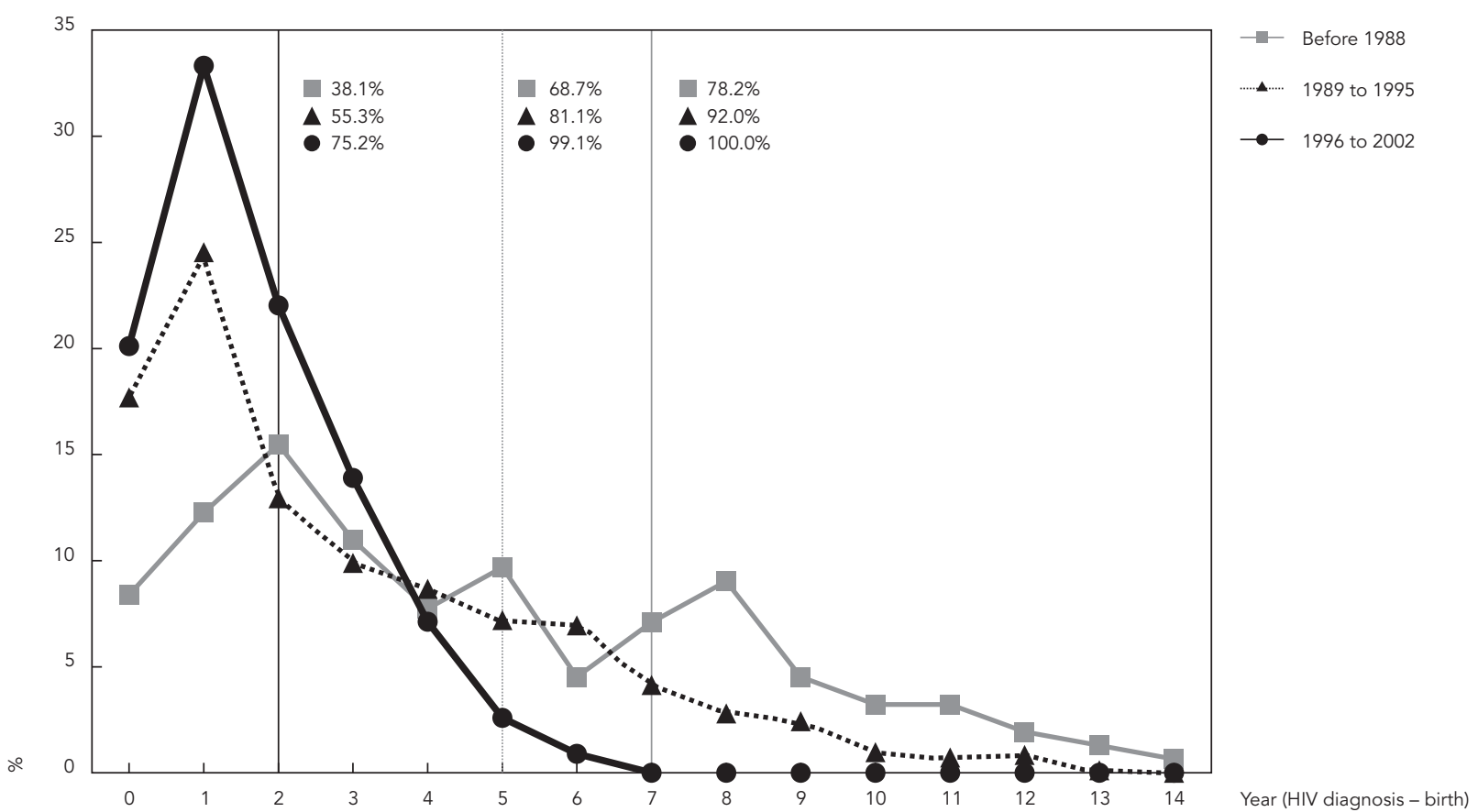

Table 2

Descriptive statistics of first absolute CD4+ lymphocyte count in children from the second Brazilian national survival study (1999 to 2002) by child status and age group.

\begin{tabular}{lccc}
\hline Parameters & & Age group (years) & $\mathbf{6 - 1 2}$ \\
& $<1$ & $\mathbf{1 - 5}$ & $107(5.8)$ \\
\hline Total [n (\%)] & $254(13.7)$ & $584(31.4)$ & $90(84.1)$ \\
CD4 count available [n (\%)] & $171(67.3)$ & $502(86.0)$ & 281.2 \\
Mean & 331.9 & 413.5 & $226.7-335.6$ \\
$95 \% \mathrm{Cl}$ & $293.4-370.4$ & $387.4-439.5$ & 195.5 \\
Median & 204.0 & 346.5 & 0 \\
Minimum & 10 & 1 & 948
\end{tabular}

95\% Cl: 95\% confidence interval.

era, these diseases, especially bacterial diseases, are still common. The data emphasizes the need to scale up actions directed at the prevention of mother-to-child transmission, early diagnosis, and improvements in comprehensive pediatric care. The following variables are significantly associated with the occurrence of these events: place of residence, being under the age of 12 months at the time of diagnosis, and inadequate mother-to-child transmission prevention measures 15 .

In 2006, the Brazilian government adopted the Pact for Life that formed the basis for structuring the National Plan for the Reduction of 
Mother-to-Child Transmission of HIV and Syphilis with the goal of strengthening HIV control actions and reducing infant and maternal mortality $12,39,40$. Additionally, considering the achievements of the Brazilian National Health Policy after 2002, particularly in primary health care, it is possible that these scenarios will be modified 41 beyond the results of the periods investigated by this study 42 . Considering these possible new scenarios, future studies in this area may indicate a different situation in the country where missed opportunities are reduced. It is important to note that significant regional disparities exist, especially in poorer regions, such as the north of Brazil. Policies therefore need to focus on improving the reach of actions across the country $15,16,21,24,25$.

The possible limitations of this study are typical to survival studies and have been discussed in detail by other authors 17,19,20,21. One such limitation is the loss of cases due to the poor quality of Brazilian Ministry of Health databases and medical records. The number of cases found by this study may be lower than expected due to underreporting in the surveillance systems; however, this is unlikely to have caused trend bias in the periods analyzed by this study 20 . Another possible limitation is that children were included in the study based on a retrospective analysis of infection diagnosis. Considering that half of the sample was born in the post-HAART era, this may have led to an overestimation of the relevance of diagnostic delay, since children that had not progressed to AIDS were not included. Thus, this sample may not be representative of the population of HIV-infected children in Brazil. Despite these potential limitations, an advantage of this database is that it is representative of the general population and has therefore been used consistently in various strategic studies 12 .

\section{Conclusion}

Whether or not undiagnosed children should receive early therapy continues to be controversial issue. International guidelines clearly advocate early therapy in children already diagnosed which HIV infection.

Our results highlight that, despite advances in HIV/AIDS control policies after 1996, a large proportion of HIV-infected children in Brazil were diagnosed at a late stage. This study emphasizes the lack of health system capacity to ensure early HIV diagnosis in children and failure to prevent mother-to-child transmission, despite substantial investment by the Brazilian government over the last 30 years. These findings emphasize the need for improvements in the prevention of mother-to-child HIV transmission, disease management, considering the specific needs of each age group, and in the treatment of opportunistic diseases in children.

\section{Resumen}

Se analizaron datos de dos cohortes retrospectivas consecutivas (1983-1998, 1999-2002) de niños brasileños con SIDA ( $N=1.758)$, expuestos al VIH por transmisión vertical. La ocurrencia de diagnóstico tardio (categoría C-CDC) fue verificada para: año de nacimiento, año de diagnóstico de la infección y períodos relacionados con cambios de las directrices terapéuticas gubernamentales. Hubo 731 (41,6\%) niños con diagnóstico en estadio tardio, especialmente con $<1$ año de edad. En el segundo período el desempeño del diagnóstico mejoró (36 versus 48\% de atraso diagnóstico). Se verificó una mejoría de la proporción de niños con diagnóstico tardío y del tiempo entre diagnóstico de la infección e introducción de la terapia antirretroviral. Los años de nacimiento $(O R=0,62 ; p=0,009)$ y años de diagnóstico de la infección (OR =0,72; $p=0,002 / O R=0,62 ; p<$ $0,001)$ más recientes estuvieron significativamente asociados a un diagnóstico oportuno. Los niños con edad < 1 año tuvieron mayor riesgo para un diagnóstico tardio que los más viejos $(O R=1,70 ; p=0,004)$. A pesar de los avances, existe una necesidad de potenciar el diagnóstico y tratamientos oportunos.

VIH; Diagnóstico Tardío; Niño 


\section{Contributors}

A. N. Ramos Jr. and L. H. Matida contributed to study conception and design, the literature search, article selection, data extraction and analysis and the drafting of this manuscript. C. H. Alencar and N. Hearst contributed to data analysis and the drafting of this manuscript J. Heukelbach contributed to article selection, data analysis and the drafting of the manuscript.

\section{Acknowledgments}

The authors are grateful to the technical coordination team of the Brazilian Study Group on Survival of Children with AIDS including, Alberto Novaes Ramos Jr. Heloisa H. S. Marques, Jörg Heukelbach, Luiza H. Matida, Marinella D. Negra, Norman Hearst, and Regina C. M. Succi. This work received technical and financial support from the Brazilian Department of STD, Aids and Viral Hepatitis of the Ministry of Health/Secretariat of Health Surveillance through the International Technical Cooperation Project.

\section{References}

1. Mofenson LM. Prevention in neglected subpopulations: prevention of mother-to-child transmission of HIV infection. Clin Infect Dis 2010; 50 Suppl 3:S130-48.

2. Brady MT, Oleske JM, Williams PL, Elgie C, Mofenson LM, Dankner WM, et al. Declines in mortality rates and changes in causes of death in HIV-1infected children during the HAART era. J Acquir Immune Defic Syndr 2010; 53:86-94.

3. Dunn D, Woodburn P, Duong T, Peto J, Phillips A Gibb D, et al. Current CD4 cell count and the shortterm risk of AIDS and death before the availability of effective antiretroviral therapy in HIV-infected children and adults. J Infect Dis 2008; 197:398-404

4. Hazra R, Siberry GK, Mofenson LM. Growing up with HIV: children, adolescents, and young adults with perinatally acquired HIV infection. Annu Rev Med 2010; 61:169-85

5. Violari A, Cotton MF, Gibb DM, Babiker AG, Steyn J, Madhi SA, et al. Early antiretroviral therapy and mortality among HIV-infected infants. N Engl J Med 2008; 359:2233-44.
6. Zanchetta M, Anselmi A, Vendrame D, Rampon O, Giaquinto C, Mazza A, et al. Early therapy in HIV1-infected children: effect on HIV-1 dynamics and HIV-1-specific immune response. Antivir Ther 2008; 13:47-55.

7. Levy JA. HIV pathogenesis: 25 years of progress and persistent challenges. AIDS 2009; 23:147-60.

8. Patel K, Hernán MA, Williams PL, Seeger JD, McIntosh K, Van Dyke RB, et al. Long-term effective ness of highly active antiretroviral therapy on the survival of children and adolescents with HIV infection: a 10-year follow-up study. Clin Infect Dis 2008; 46:507-15.

9. Ciaranello AL, Chang Y, Margulis AV, Bernstein A, Bassett IV, Losina E, et al. Effectiveness of pediatric antiretroviral therapy in resource-limited settings: a systematic review and meta-analysis. Clin Infect Dis 2009; 49:1915-27.

10. Nunn AS, Fonseca EM, Bastos FI, Gruskin S. AIDS treatment in Brazil: impacts and challenges. Health Aff (Millwood) 2009; 28:1103-13. 
11. Ramos Jr. AN, Matida LH, Hearst N, Heukelbach J. AIDS in Brazilian children: history, surveillance, antiretroviral therapy and epidemiological transition, 1984-2008. AIDS Patient Care STDS 2011; 25: 245-55.

12. STD, AIDS and Viral Hepatitis Department, Health Surveillance Secretariat, Brazilian Ministry of Health. Targets and commitments made by member-states at the United Nations General Assembly Special Session on HIV/AIDS. Brazilian response 2008-2009: country progress report. http://data. unaids.org/pub/Report/2010/brazil_2010_coun try_progress_report_en.pdf (accessed on 10/ Oct/2011).

13. Hacker MA, Kaida A, Hogg RS, Bastos FI. The first ten years: achievements and challenges of the Brazilian program of universal access to HIV/AIDS comprehensive management and care, 1996-2006. Cad Saúde Pública 2007; 23 Suppl 3:S345-59.

14. Ramos Jr. AN, Matida LH, Hearst N, Heukelbach J. Mortality in Brazilian children with HIV/AIDS: the role of non-AIDS-related conditions after highly active antiretroviral therapy introduction. AIDS Patient Care STDS 2011; 25:713-8.

15. Ramos Jr. AN, Matida LH, Hearst NG, Heukelbach J. Opportunistic illnesses in Brazilian children with AIDS: results from two national cohort studies, 1983-2007. AIDS Res Ther 2011; 8:23.

16. Ramos Jr. AN, Matida LH, Saraceni V, Veras MASM, Pontes RJS. Control of mother-to-child transmission of infectious diseases in Brazil: progress in HIV/AIDS and failure in congenital syphilis. Cad Saúde Pública 2007; 23 Suppl 3:S370-8.

17. Matida LH, Ramos Jr. AN, Heukelbach J, Sañudo A, Succi RCM, Marques HHS, et al. Improving survival in children with AIDS in Brazil: results of the second national study, 1999-2002. Cad Saúde Pública 2011; 27 Suppl 1:S93-103.

18. Souza-Júnior PR, Szwarcwald CL, Castilho EA. Delay in introducing antiretroviral therapy in patients infected by HIV in Brazil, 2003-2006. Clinics 2007; 62:579-84

19. Matida LH, Marcopito LF, Succi RC, Marques HH, Della Negra M, Grangeiro A, et al. Improving survival among Brazilian children with perinatallyacquired AIDS. Braz J Infect Dis 2004; 8:419-23.

20. Matida LH, Ramos Jr. AN, Heukelbach J, Hearst N. Continuing improvement in survival for children with acquired immunodeficiency syndrome in Brazil. Pediatr Infect Dis J 2009; 28:920-2.

21. Matida LH, Ramos Jr. AN, Moncau JEC, Marcopito LF, Marques HHS, Succi RCM, et al. AIDS by mother-to-child transmission: survival analysis of cases followed from 1983 to 2002 in different regions of Brazil. Cad Saúde Pública 2007; 23 Suppl 3: S435-44.

22. Centers for Disease Control and Prevention. 1994 revised classification system for human immunodeficiency virus infection in children less than 13 years of age. MMWR Recomm Rep 1994; 43:1-10.

23. Tess BH, Rodrigues LC, Newell ML, Dunn DT, Lago TD. Breastfeeding, genetic, obstetric and other risk factors associated with mother-to-child transmission of HIV-1 in Sao Paulo State, Brazil. AIDS 1998; $12: 513-20$
24. Succi RCM; Grupo de Estudo da Sociedade Brasileira de Pediatria para Avaliar a Transmissão Materno-Infantil do HIV. Mother-to-child transmission of HIV in Brazil during the years 2000 and 2001: results of a multi-centric study. Cad Saúde Pública 2007; 23 Suppl 3:S379-89.

25. Ramos Jr. AN, Matida LH, Hearst N, Heukelbach J. AIDS morbidity and mortality in Brazilian children before and after highly active antiretroviral treatment implementation: an assessment of regional trends. Pediatr Infect Dis J 2011; 30:773-7.

26. Matida LH, Santos NJ, Ramos Jr. AN, Gianna MC, Silva $\mathrm{MH}$, Domingues CS, et al. Eliminating vertical transmission of HIV in São Paulo, Brazil: progress and challenges. J Acquir Immune Defic Syndr 2011; 57 Suppl 3:S164-70.

27. Diaz C, Hanson C, Cooper ER, Read JS, Watson J, Mendez HA, et al. Disease progression in a cohort of infants with vertically acquired HIV infection observed from birth: the Women and Infants Transmission Study (WITS). J Acquir Immune Defic Syndr Hum Retrovirol 1998; 18:221-8.

28. Goetghebuer T, Haelterman E, Le Chenadec J, Dollfus C, Gibb D, Judd A, et al. Effect of early antiretroviral therapy on the risk of AIDS/death in HIV-infected infants. AIDS 2009; 23:597-604.

29. Newell ML, Coovadia H, Cortina-Borja M, Rollins N, Gaillard P, Dabis F, et al. Mortality of infected and uninfected infants born to HIV-infected mothers in Africa: a pooled analysis. Lancet 2004; 364:1236-43.

30. Dunn D; HIV Paediatric Prognostic Markers Collaborative Study Group. Short-term risk of disease progression in HIV-1-infected children receiving no antiretroviral therapy or zidovudine monotherapy: a meta-analysis. Lancet 2003; 362:1605-11.

31. Boyd K, Dunn DT, Castro H, Gibb DM, Duong T, Aboulker JP, et al. Discordance between CD4 cell count and CD4 cell percentage: implications for when to start antiretroviral therapy in HIV-1 infected children. AIDS 2010; 24:1213-7.

32. Programa Nacional de DST e Aids, Secretaria de Vigilância em Saúde, Ministério da Saúde. Recomendações para terapia antirretroviral em crianças e adolescentes infectados pelo HIV: manual de bolso. Brasília: Ministério da Saúde; 2009. (Série Manuais, 85).

33. Palladino C, Bellón JM, Jarrín I, Gurbindo MD, De José MI, Ramos JT, et al. Impact of highly active antiretroviral therapy (HAART) on AIDS and death in a cohort of vertically HIV type 1-infected children: 1980-2006. AIDS Res Hum Retroviruses 2009; 25:1091-7.

34. Patel K, Hernán MA, Williams PL, Seeger JD, McIntosh K, Dyke RB, et al. Long-term effects of highly active antiretroviral therapy on CD4+ cell evolution among children and adolescents infected with HIV: 5 years and counting. Clin Infect Dis 2008; 46:1751-60.

35. Sutcliffe CG, van Dijk JH, Bolton C, Persaud D, Moss WJ. Effectiveness of antiretroviral therapy among HIV-infected children in sub-Saharan Africa. Lancet Infect Dis 2008; 8:477-89. 
36. Mofenson LM, Brady MT, Danner SP, Dominguez KL, Hazra R, Handelsman E, et al. Guidelines for the prevention and treatment of opportunistic infections among HIV-exposed and HIV-infected children: recommendations from CDC, the $\mathrm{Na}$ tional Institutes of Health, the HIV Medicine Association of the Infectious Diseases Society of America, the Pediatric Infectious Diseases Society, and the American Academy of Pediatrics. MMWR Recomm Rep 2009; 58:1-166.

37. Weinberg A, Dickover R, Britto P, Hu C, PattersonBartlett J, Kraimer J, et al. Continuous improvement in the immune system of HIV-infected children on prolonged antiretroviral therapy. AIDS 2008; 22:2267-77.

38. Chiappini E, Galli L, Tovo PA, Gabiano C, Lisi C, Gattinara GC, et al. Changing patterns of clinical events in perinatally HIV-1-infected children during the era of HAART. AIDS 2007; 21:1607-15.
39. Ramos Jr. AN, Matida LH, Hearst N, Heukelbach J. High occurrence of HIV-positive siblings due to repeated mother-to-child-transmission in Brazil. AIDS Care 2012; 24:601-5.

40. Programa Nacional de DST e Aids, Secretaria de Vigilância em Saúde, Ministério da Saúde. Boletim Epidemiológico, Aids e DST 2009; Ano VI, n. 1.

41. Guanais FC, Macinko J. The health effects of decentralizing primary care in Brazil. Health Aff (Millwood) 2009; 28:1127-35.

42. Macinko J, Guanais FC, Fatima M, de Souza M. Evaluation of the impact of the Family Health Program on infant mortality in Brazil, 1990-2002. J Epidemiol Community Health 2006; 60:13-9.

Submitted on 08/Jun/2012

Final version resubmitted on 19/Dec/2012

Approved on 14/Feb/2013 